Article

\title{
Eastern Orthodox Christianity and the Uses of the Past in Contemporary Greece
}

\author{
Victor Roudometof \\ Department of Social and Political Sciences, University of Cyprus, PO Box 20537, Nicosia 1678, \\ Cyprus; E-Mail: roudomet@ucy.ac.cy
}

Received: 15 March 2011; in revised form: 12 April 2011 / Accepted: 4 May 2011 /

Published: 11 May 2011

\begin{abstract}
The article examines the use of Orthodox Christianity in the debates over the cultural heritage of contemporary Greece. Since the birth of modern Greece, Orthodox Christianity has been used as one of the foundational cultural markers for the construction of Modern Greek national identity. This employment of religion is particularly evident in the case of history in its popularized format. In contemporary cultural politics, debates over the building of a mosque in Athens or the role of Orthodoxy in history textbooks offer particular illustrations of the public significance of Orthodox Christianity. This high profile role was particularly pronounced during the reign of the late Archbishop Christodoulos (1998-2008). The article suggests that the engagement and influence of the Church on public debates depends upon the nature of the affair: The Church enjoys more authority in ecclesiastical issues and is far less influential on issues of broader interest, such as geopolitical disputes.
\end{abstract}

Keywords: Eastern Orthodox Christianity; heritage; Greece; politics; culture

\section{Introduction}

The varied and most frequent political use of the past is a well-documented avenue of research for historians and social scientists (see, for example, Levi and Revel [1]). Cultural heritage is a facet of the concern with the collective memory of modern societies (for a discussion, see Roudometof [2]). Perception of what constitutes heritage is, after all, the result of the way societies remember their own past, their collective memory. In traditional society, memory was experienced directly in several realms. In contrast, modernization has eroded the realms of memory, thereby causing the 
disembodiment of memory [3]. Similarly, in pre-modern societies cultural heritage was a feature of the upper classes and formed part of their cultural capital. In contrast, in modern societies heritage has been democratized. It has become a property of the people under the guise of national heritage ([4], pp. 60-68). This nationalization of heritage is partly responsible for the proliferation of the concern with heritage around the world ([5], p. 13).

Debates over heritage and memory often feature religion, as such, or religiously-defined themes and topics. From France's l'affairre de mandil to the publication of cartoons of Prophet Mohammed in Denmark to the decision of banning the building of an Islamic mosque in Switzerland, religion has made a return to the European public scene. This return has important cultural and political ramifications. These intense "culture wars" [6] feature new battle lines that cut across the political spectrum. The new battlegrounds include the orientation of European societies vis-à-vis the European project, the role of national heritage, national memory, religion and culture in national identity and the way national identity is impacted by Europeanization, by immigration and, more generally, by all the multitude of real or imagined processes that are typically subsumed under the rubric of globalization. In the U.S., such debates have been framed in terms of Taylor's [7] notion of the "politics of recognition." However, in continental societies different states exhibit considerable variation in their efforts to come to terms with multiculturalism [8].

Greece's debates on these issues mirror the European engagement with these issues. In this article, I situate and analyze the role of Eastern Orthodox Christianity in contemporary debates over Greece's cultural heritage and memory. I explicitly aim at placing these debates within the broader cultural and political context of the dilemmas facing the Greek state and Greek society in the early 21 st century. In the article's opening part, I briefly outline the historical role of Orthodox Christianity in the construction of modern Greek identity. Next, I move to discuss contemporary developments and concentrate on key contemporary topics in which the role of Orthodox Christianity and the Church of Greece has occupied central stage. Then, I outline the polemical standpoints that pertain to the debate about contemporary Greek culture and situate the role of the Orthodox Church of Greece in the context of this broader debate. Last, I address the issue of nationalism, which is of particular significance for Greece-especially because of its connection to on-going geopolitical rivalries vis-à-vis some of its neighboring states.

\section{Orthodox Christianity and Modern Greek Identity: A Brief Primer}

Just like in several other European nations (such as Poland or Ireland) the role of religion in Greece's history has been extremely important. Greece has fostered several distinct religious cultures, ranging from Ancient Greek polytheism to Christian monotheism (for an overview, see Makrides [9]). Today, though, over $90 \%$ of the population of Greece is Orthodox Christians, and therefore speaking about the role of religion in contemporary Greece is identical in many respects to addressing the role of Orthodox Christianity in the country's public life and national culture. This generalization is not meant to disregard the important role several religious minorities have played in the country's history or also the existence of contemporary Muslim and other religious minorities in contemporary Greece (for a discussion, see Yannas [10]). 
Just as with other forms of Christianity in Europe, in the course of the last few centuries, Eastern Orthodox Christianity has been absorbed into the fabric of Modern Greek national identity. Although Greece has a long history of engagement with Western Europe, its social, economic and cultural trajectory follows not that of the developed Western European societies but, rather, the semi-peripheral societies of Southeastern Europe.

During the Ottoman era, the Orthodox Church played a very important role thanks to its role in the Ottoman Empire's taxation system. In the context of the Ottoman millet system, the Church often assumed the responsibility of tax collection. In the 1821 Greek revolution, membership in the nation was often cast in religious terms, whereby all Orthodox subjects to the Sultan were considered as potentially belonging to the emerging Greek nation. This definition grew out of the Orthodox subjects' official classification as members of the Ottoman Rum Millet, the mixed political-religious category of classification in operation in the Ottoman Empire. According to that system of classification, all Orthodox were included in a singular category of the zimmi-the "people of the book" who were accorded protected status in accordance with the Koran [11]. The transformation of this category into a national category of classification is beyond the scope of discussion in this article. However, it should suffice to say that this transformation was gradual and the employment of Orthodox faith for the purposes of defining the unredeemed Greeks was of considerable importance. The systematic association between modern Greece and Orthodox Christianity is a feature of the 19th century when a modern synthesis between Orthodox Christianity and modern Greek identity took place [12], whereby membership in the Greek nation was defined partly in terms of confessional membership in specific ecclesiastical institutions (the post-1833 Church of Greece, the Ecumenical Patriarchate and some additional independent churches, such as the Church of Crete and the Church of Cyprus). Of key importance for this fusion was the invention and deployment of a new term (ellinochristianismos or Greek Christianity), which exemplified linguistically this contemporary fusion. The debates and conflicts over the role of religion (and of Eastern Orthodox Christianity in particular) in nation building are very much part of the history of 19th and early 20th century Balkans. The extent of their importance is revealed once one considers that the 1923 Lausanne Treaty - a treaty that explicitly stipulated population exchanges between Greece and the newly established Republic of Turkeyassigned the labels "Greek" and "Turk" to Orthodox and Muslims, respectively [13]. In other words, up until the 20th century Eastern Orthodox Christianity was used as the principal criterion for inclusion of a person in Greece's "imagined community" [14]. The cultural homogenization of modern Greece's population was predicated on using membership in Orthodox Christianity as a foundational category for setting the nation's cultural boundaries [15], and therefore for defining "insiders" and "outsiders" to the nation [16].

Until 1945, the mostly Orthodox nation-states of southeastern Europe were traditional societies in which the majority of the population was engaged in agriculture and similar pursuits. After World War II these societies - including Greece-were urbanized for the very first time in their modern history (for a discussion, see McNeil [17]). This rapid urbanization altered the traditional moral bases of their cohesion. In the Greek case, this trend is manifested in the post-World War II statistics on religious attendance that show a clear decline in the rates of regular church attendance between the early 1960s and 1980s (for data and analysis, see Georgiadou and Nikolakopoulos [18] and Makrides [19]). 
However, this decline in church attendance does not by any means suggest a decline in religion's public role in Greece. On the contrary, during the 1967-1974 military dictatorship, the regime's official policy was the pursuit of the creation of a "Greece of Christian Greeks" (as was the official state slogan during the junta). The military dictatorship made extensive use of the previously established notion of "Greek Christianity" and aptly applied this ideology of "Hellenic Christian civilization" to the realm of public culture and state policy ([20], pp. 34-50). The 1974 restoration of democracy caused the overnight collapse of this ideology, which was almost instantly delegitimized. It took more than a decade to have religion resurface forcefully into the public realm.

The 1989 collapse of communism in Eastern Europe was a major turning point for the history of modern Greece, and it offered the opportunity to reassert the Church of Greece's role in contemporary cultural politics. In the aftermath of communism's collapse, the influx of close to a million legal and illegal immigrants into Greece seriously affected Greek society by producing a series of challenges on issues of religious pluralism and multicultural coexistence. Additionally, since 1989, there has been a new phase in European Union (EU) developments; these included the Maastricht Treaty (1992), the introduction of the Euro and EU's 2004 Eastern European enlargement. As a result, the Orthodox Church of Greece found itself in a new and evolving social and cultural landscape. The EU and various Europeanization projects spearheaded by the state and supranational institutions sought to provide a legal and institutional framework for registering this new situation into state legislature and administrative practice. Various legislative initiatives attempted to privatize religion by threatening to restrict the Church's authoritative role on a range of issues (cremation, catechism, civil marriage ceremonies, etc.).

The Orthodox Church reacted to these multiple challenges by re-entering the public domain forcefully in order to reassert its traditional privileged legal, social and cultural status. Its efforts have been variously referred to as the "politicization" of the Church or the "de-privatization" of Orthodoxy [21-23]. The politicization of Orthodoxy has been expressed in a variety of issues raised in the context of church-state relations: Cremation, catechism in Greek public schools, the status of civil versus church weddings, the Church's role in providing welfare for ethnic Greeks alone (vs. Muslim-Greek citizens), the construction of a mosque in Athens, the status of the oath in public ceremonies and the rights of religious minorities are all topics of great concern that involve the state and its relationship to the Orthodox Church. But the de-privatization of religion has been expressed also in a tapestry of topics pertaining to the relationship between Orthodox Christianity and the broader Greek society and culture; for example, the Church's role in welfare, the use of popular music to convey religious messages and the efforts to come to terms with the role of women in the Church are all examples of a renewed relationship between Orthodoxy and modern Greek culture (for examples, see Roudometof and Makrides [24]).

By way of introducing this entire problematique, it is important to draw a distinction between the more narrowly defined ecclesiastical matters and more middle-range topics of public discourse. The distinction proposed here concerns a division between those issues in which the Church enjoys an authoritative position - that is, topics that fall within the preview of ecclesiastical legislation-versus an array of issues that require the agreement and/or participation of non-ecclesiastical agencies. For example, the Church is authorized to render decisions over the acceptance of civil weddings, and such decisions can be enforced by the local priests. The Church is also capable to offer welfare to ethnic 
Greeks alone, as such an action is does not require the State's approval. Similarly, the Church can authoritatively declare that cremation is not an accepted option for Orthodox Christians. In contrast, the Church is not in a position to decide or enforce the listing of religious identification onto Greek ID cards - the authority rests with the State.

While it might seem that the division between these two sets of issues is clear-cut, it is worth pointing out that the boundary between the two sets of issues is not a "hard" one. Rather, it is porous. For example, the teaching of catechism in Greek schools, which the Church considers a high priority, is not a matter decided by the Church itself but rather by Greece's Ministry of Education. Similarly, the listing of religious identification onto Greek ID cards is a matter of State responsibility. In fact, the Church hierarchy seems fully aware of these issues' porous boundaries. It is precisely because on numerous topics the Church's role is only advisory that the final outcome rests on the Church's ability to enter into the public realm and forcefully propagate its own position. By means of entering into public discourse the Church hierarchy extends its reach and enhances its moral authority, thereby effectively lobbying public opinion and state bureaucracy toward favorable positions. By and large, this was a strategy for the most part rather successfully followed during the ten-year reign of the late Archibshop Christodoulos (1998-2008).

\section{The Orthodox Church of Greece in Contemporary Debates}

Christodoulos's tenure signaled a period of a multifaceted Church modernization. His charisma and TV-friendly persona turned him for a period of time into one of the most popular of the public figures in the country [25] (for an analysis see Oulis, Makris and Roussos [26]). Certainly, during Christodoulos's rule, official pronouncements and other forms of action by the Orthodox Church of Greece enhanced its status as a key agent participating in these cultural wars. For Christodoulos [27], as well as other defenders of the modern synthesis of church and nation, Orthodoxy is a chain of national memory [28]. The late archbishop routinely reminded his audience of the critical role of religion in the preservation of Greek national identity in past centuries:

Hellenism cannot live without visions and hope. Only if the castle of our memory remains unconquered and maintained by our legends and those who incarnate our National Idea, only then can our Genos (Race or Progeny) become glorious. And our Genos can survive only if it embraces again the life-giving Greek-Orthodoxy ([27], p. 52).

This perspective earned the late archbishop both ardent supporters and vehement critics. Certainly, the Left saw in him an epigone of the mentality of the nationalists, the ultra-right wing faction of the Right and other anti-communist forces. But even neo-liberal thinkers-such as former minister and free market promoter Andreas Andrianopoulos [29] — have expressed reservations about the strong advocacy of the church-nation link asserted in Christodoulos's discourse and the siege mentality often evoked in his speeches and other forms of public communication. It is also worth adding that, while the late Archbishop was a charismatic public speaker, his own positions were not immune to criticisms by other higher clergy (such as the Metropolitans of Zakynthos, of Epirus, or of Peristeri) who at times made their own public interventions. 
In this regard, it is important to highlight the fact that the late archbishop's position was neither idiosyncratic nor isolated from the broader tenets of conventional ecclesiastical discourse. The assertion of the church-nation link is actually typical and fully in line with the 19th century modern synthesis between church and nation. In an analysis of the encyclicals of the Holy Synod of the Orthodox Church of Greece for the period between 1833 and 2000, Papageorgiou [30] finds that this assertion has always informed the self-image of the church hierarchy. In the eyes of the hierarchy, religion, family and homeland are thus the cornerstones of Greek society as such. Papageorgiou ([30], p. 284) concludes that the Church's image is that of traditionalism and the past, "a closed system that is connected to the values of the past without attempting openings toward . . . the present and the future." In fact, the encyclicals reveal the Synod's identification of itself with the Church as an institution thereby excluding the laity from being active members in the workings of the institution. In conjunction with the legal ethics that prevail in the texts, the Church's self-image is that of a bureaucracy that exists in collaboration with the state and often acts as an extension of public authority in a hierarchical manner vis-à-vis its members. So, Christodoulos was far less exceptional in the substance of his approach and thinking than most critics often assume. Defending the modern synthesis of church and nation has been an approach consistently voiced by Greece's ecclesiastical hierarchy for most of its modern history.

By far the most visible and the most well-publicized controversy of the Christodoulos era (1998-2008) was the 2000 ID crisis, when the Church of Greece publicly disagreed with the Greek government over whether the new ID cards should include an entry for religious affiliation. The state openly supported the introduction of new ID cards for Greek citizens that would no longer include religious affiliation on them. Although the Greek government insisted that EU regulations prohibited such a disclosure, the Church opted for voluntary disclosure, leading to a protracted public crisis (for analyses, see Danopoulos [31], Prodromou [32], Roudometof [22] and Stavrakakis [23]). The images of Greek bishops and believers protesting against the Greek government's effort to institute new ID cards that would exclude an entry for religious affiliation were widely circulated among the European public [33-36]. This episode marked not only a new era of church-state relations but also a turning point in the relationship between the Orthodox Church and the Greek public. Outside Greece, the ID crisis also contributed greatly to the proliferation of a negative image of the Orthodox Church. The Church's image was that of an anti-modern institution set against the forces of modernization and Europeanization. This issue was clearly one where the State enjoyed full legal authority, and therefore the Church could only use its influence and public voice to shape legislation according to its own interests.

But it is important to note that the ID crisis has been part of a broader range of topics that have marked the forceful reappearance of the Church in public life. This list of the various "hot issues" includes the prohibition of catechism, the public operation of mosques and denominational churches, the issue of cremation and the issue of burial rites and baptism for individuals who have chosen to have a civil wedding ceremony (which the Church does not officially recognize as valid) instead of a religious ceremony [37,38]. In several of these issues, the Church has to rely on the actions of the State to safeguard its own positions. Therefore, the soft boundary that separates the strictly ecclesiastical issues from those that fall within the realm of state policy and public discourse demands the high clergy's participation and intervention into public debates as a means of shaping public opinion. 
Underneath the emergence of these topics as areas of public contestation lies Greece's participation in the EU. Since 1990, these topics have surfaced as a result of the state facing the necessity to implement policies consistent with EU's vision of cultural (including religious) pluralism, whereas the Church's own stance has been to attempt to prevent the loss of its privileged position in society and in its dealings with the state.

The majority of these aforementioned topics have been discussed in greater detail in the literature. Beyond this list, though, since 2000, there have been some additional controversies that have evolved around the Orthodox Church of Greece, either as part of the public debate or directly, through the actions of its hierarchs. In the following paragraphs I offer a brief overview of these relatively more recent cases.

1. The Mosque debate over the construction of an Islamic Mosque in downtown Athens. This debate has its origins in government-sponsored legislation introduced in anticipation of the 2004 Athens' Olympic Games. Needless to say, more than a decade has passed since the introduction of legislation, yet no mosque has been built. The issue of building an Islamic mosque and an adjacent Muslim cultural centre has become a protracted subject of political and ideological controversy. Contrary to simplistic accounts, the Church hierarchy itself is not one of the principal opponents of the project. Rather, the hierarchy attempts to navigate between different constituencies by adopting flexible perspectives that allow the preservation of amicable relations with all parties [39]. The main constituency seems to be a group of radical Right and almost fundamentalist-like Christians who operate as a pressure group both upon the Church and the government alike.

2. The Parthenon video affair. Following the opening of the Athens' Acropolis Museum in 2009 a major controversy erupted over a video presentation that was prominently featured in the museum. The video was the work of French-Greek director Costa Gravas. It contains a reference to damage done to the Parthenon in the first Christian centuries and, for a brief period, it shows images of people dressed in seemingly religious dress (which was common clothing during those centuries) destroying the Parthenon's sculptures. Upon the opening of the museum, members of the Church's hierarchy protested over what they deemed to be an inappropriate reference to the Church. In effect, they argued that the video insinuated that the Church was responsible for damage done to the Parthenon. The government's initial reaction was to censor the video by deleting the controversial images from the video. But this action in turn led to Costa Gravas' public and vocal protests in which he called for his work to be removed from the exhibit altogether. Finally, after a year and an on-line protest campaign, the government reversed its initial decision and let the entire video be displayed in its original version [40].

3. The textbook affair of 2007. During the 2006-2007 academic year a major debate erupted in the Greek media over the introduction of new history textbooks in Greece's elementary and middle-level schools. The scandalous issue pertained to the issue of a new history textbook for sixth graders (a copy of the textbook is available from Antivaro [41]). Critics claimed that the new textbook was full of mistakes and that it was also insulting to Greece's national memory. At issue was the attempt to provide a less nationalistic account of past historical events by presenting Greek history in schools differently than it had been. Religion was implicated in the affair to the degree that the textbook did not contain references to such cherished topics such as the legend of the "secret school." 
According to this national legend, Greek educational institutions and schools were closed down during the period of Ottoman rule. Orthodox clergy schooled Greek students at night in secret. Suffice to say, this national myth originated in 19th century public commemorations of the Greek War of Independence. In the context of such occasions poetic license gradually gave rise to a powerful national myth [42]. When new history textbooks were sent to elementary schools in 2006-2007, parents, intellectuals and journalists complained that the new textbook failed to make any reference to this sacred national myth. When history professors proceeded to publicly explain that the secret school is but a myth, journalists, politicians and many intellectuals reacted with dismay and disbelief, creating media frenzy that swept the Greek TV talk shows for the better part of March 2007.

Mrs. M. Giannakou, Minister of Education at the time, defended the process and tried to appease the opposition [43]. Her successor to the Ministry of Education moved swiftly to postpone the circulation of the new textbooks, thereby bowing to public sentiment. In fact, press reports attributed her failure to get re-elected to parliament in the next national elections to the impact of this affair.

4. The public discussion sparked in the first half of 2011 by the TV documentary series "1821". The series centered on Greece's 1821-27 National War of Independence. It was broadcasted by SKAI TV in eight episodes, with one-hour roundtable discussions following each episode's broadcast. The series became almost instantly controversial with public commentaries protesting over the interpretation of numerous historical events - ranging from the status of Greeks under Ottoman rule to the Church's portrayal in the series. In at least one of these roundtable discussions, this last issue was explicitly raised by bishop of Thessaloniki Anthimos [44]. The criticism against the series' portrayal of the role of the Church of Greece during the period of Ottoman rule and the revolution concerned the lack of attentiveness to the Church's "national role" and its depiction as an institution incorporated into the Ottomans' bureaucracy.

\section{Battle Lines in Contemporary Greek Culture}

As the discussion in this article's first section has illustrated, in Greece the debate over national heritage and cultural identity includes not only the role of the Orthodox Church of Greece in broader society but also the attitudes and policy vis-à-vis the millions of Greece's legal and illegal immigrants, the teaching and interpretation of history in the Greek schools and so on. In these intense ideological and cultural conflicts, public intellectuals play prominent roles. As a result, culture wars between conservative and progressive intellectuals often center on issues of national heritage.

Although strongly colored by political partisanship, these cultural-political contests feature relatively well-defined groups of intellectuals with competing public agendas. On the one side of this cultural battlefield one can easily locate the "defenders of the nation," who routinely suggest that Greece is under siege by forces aiming to undermine its national identity, territorial integrity, state sovereignty and the central role of Orthodox Christianity in defining Greekness. Against them one can also easily find an opposing group of "modernizing intellectuals," who eagerly suggest that their ideological adversaries are nothing else than "reactionaries" bent on keeping Greece away from the European project and social, political and cultural modernization [45]. The modernizing intelligentsia's vision is one of full engagement with the EU's supranational institutions with the clear objective of adjusting Greek institutions to international norms (or at least to what is projected as the 
"proper" norms of global society). Such norms include a multicultural society, acceptance of immigrants as full participants in Modern Greek society, the expulsion of nationalistic rhetoric from both foreign policy and from public life (including schools), the endorsement of minority rights and the presumption that the Orthodox Church of Greece needs to be disentangled from the state. This is typically what is meant in public discourse by the notoriously ill-defined phrase "church-state separation".

These two public agendas have been competing for the hearts and minds of Greece's public for nearly two decades. The narratives of history woven by each side are meant to provide the template for rendering their respective positions acceptable by the public. This ongoing struggle over issues of national heritage carries with it important implications about Greece's immigration policy, its foreign policy and role in a future EU and the nature of its public sphere in the 21 st century. With regard to Orthodox Christianity in particular, there are two clearly demarcated and radically different paradigms of thinking. The first of these paradigms is conventionally referred to as "neo-Orthodox" camp. The label is certainly misleading, because there are neo-Orthodox thinkers of diverse views. Ramfos [46] and Yannaras [47], for example, are two intellectuals routinely cited as neo-Orthodox but whose interpretations of the role of Orthodox Christianity in Greece's past are quite distinct, and their evaluation of this role is at odds with each other.

In fact, for current purposes, Yannaras' positions are far more relevant, as Ramfos' interpretation of the Orthodox tradition is arguably far more critical of the ecclesiastical positions. A prominent philosopher of the Orthodox tradition, Yannaras [47] interprets the foundation of the modern Greek state and the modern construction of Greek identity as full-scale westernization of the Greek Orthodox peoples. As such, it represents a threat to the broader historical and cultural unity of Greeks with their Eastern Orthodox religious heritage. The modernization of Greece undermines Greek culture and alienates Greek people from their traditional values. Different variants of this particular interpretation is shared by several people across the political and intellectual spectrum - although obviously one has to allow for the conventional idiosyncratic divergences expected from intellectuals engaged in public discourse.

Against this "school of thought" one can easily locate a different interpretation, whereby Eastern Orthodoxy is seen as a historical barrier to Greek modernization [48-50]. Just as with the pro-Orthodox line of thinking, there is a plurality of different voices within this broader line of thinking as well. This line of interpretation is also popular amongst Greek academics. After the post-1833 establishment of an independent Church of Greece, both the hierarchy and the modern Greek state sought to cultivate a highly symbiotic relationship. The state used the clout of the Church to foster its nation-building efforts while the Church hierarchy used the state in order to maintain its hegemony in society but also to guarantee its fiscal sources - through state salaries paid to priests. Invariably, the end result was the tendency of the Church's hierarchy to side with the state and its subsequent failure to have its own autonomous voice in civil, political and cultural affairs.

This sheepish attitude is blamed on the lack of institutional differentiation between the Church and broader society and has been the subject of extensive critique [51]. Unlike its Catholic and Protestant counterparts, and just like its sister Eastern Orthodox churches throughout Eastern Europe, the Church of Greece-and for that matter, the Orthodox Church as such-does not differentiate between the institutional structure of the organization and the religious community of believers. The Church $i s$ the 
body of the publicly recognized confessional community. Unlike the West, the modernization of the Greek state did not entail the separation of church and state [52]. The organic unity of early Christian Ecclesia continues to be part of the religious self-image. Critics have argued that this semi-primordial sense of unity does not allow for a successful differentiation between Self and Other (l'Autre). As a result, the Other is not fully recognized and accepted as an autonomous agent and consequently planning society's institutions is not done on the basis of rationalization ([49], pp. 38-39). Consequently, no room is left for the impersonal principles of law, rationality and order to assume a status independent of the persons associated with them. Hence, the Greeks' religious inheritance breeds an attitude and a cultural value system that stands in the way of Greece's successful modernization. This rationale is certainly a conventional rephrasing of old-style modernization perspectives and shows how past academic programs can be transformed into public policy agendas.

Substantively, it is important that the reader should not mistake each side's description and interpretation of events as accurate reflections of the truth. It is far preferable to view these contested interpretations as the twin polar opposites or "ideal-types" of an ongoing cultural dispute over Greece's self-image. The polemical tone in this debate reflects policy positions and orientations and does not necessarily constitute an accurate or even-handed understanding and interpretation of the past [24]. Orthodox Christianity at large has had an ambiguous and multifaceted relationship with these ongoing struggles over national identity and the European project. It is often both an agent of resistance as well as an agent of engagement with topics of public discourse (for examples, see Makrides [9]). There is considerable ambivalence in the relationship between the Orthodox Church, or even more broadly, Orthodox Christianity, and modernity; and the attitude of ecclesiastical leadership, as well as individual hierarchs, priests or theologians cannot be easily grouped into a single camp. Rather, the terms of this debate effectively narrow down the entire range of interactions between religion and society into two different and polarizing options.

To the extent that compliance with EU's norms and its famous "culture of compromise" is understood as compromising Greece's national heritage, intellectuals and Church leaders have been keen on voicing their opposition-typically expressed in terms of a harsh critique against "globalization" and Europeanization. To the above, it is necessary to add the cultural influx of new mass media, which have further added to the impression of a siege upon traditional "local" institutions like the Church - a siege allegedly waged by broader "global" forces. The need to defend the nation against the "globalization threat" was voiced by late Archbishop Christodoulos ([29], p. 127), who suggested that globality means "a common hindsight and prospect based on the choices of the powerful. [It means] the decline and perhaps even disappearance of locality." Against this vision of locality Christodoulos posited Greek Orthodox particularity. In his view, the Orthodox Church is the only institution of Greek culture that is capable of resisting the centralized impulses of state-sponsored Europeanization and other global forces that would otherwise undermine Greek national identity ([28], pp. 198-201). Given that this intertwining of religion and nationalism has been used in the course of 20th century Greek history to justify the persecution of the Left by right-wing governments, it is not surprising that the Left viewed Christodoulos as a right-wing nationalist cleric more interested in partisan politics than in ecclesiastical affairs [23,25].

With regard to the Church's overall stance toward this range of topics that have consistently emerged in the public debate over the last few decades, it is important to realize the complex and 
flexible strategy of the Orthodox Church of Greece. Generally speaking, by grounding its self-image in Greek national identity, the Church has adopted a flexible strategy with respect to the state and public policy initiatives. That is, insofar as the state confirms the Church's privileged position, the Church does not complain about the state's oversight of its own affairs. In fact, the Church is willing to invoke state legislation in order to protect its own interests [13]. But whenever the state enacts legislation that would undermine the Church's privileged position, the Church is capable of publicly criticizing state authorities or campaigning against the politicians who sponsor such legislation. The Church's stance vis-à-vis various legislative efforts has been to declare such secularizing initiatives as inherently "anti-Christian" - a hard-line position that often led to recapitulation (see Nikolopoulos [53] for a review of various cases). In this manner, the Church hierarchy can successfully capitalize on the softness of the boundary separating the more clear-cut ecclesiastical issues from those that fall within the preview of the State's own imperatives.

\section{Nationalism and the Orthodox Church of Greece}

There is a third set of issues where the Church hierarchy routinely voice its own opinion. It concerns a variety of geopolitical contests involving Greece and neighboring countries. These are topics that typically fall under the rubric of foreign policy or matters of "national interest". They are hot topics of public debate, and unlike the other two sets of issues, in these issues the Church lacks any meaningful perceived or real monopoly. On the contrary, the Church of Greece's hierarchs are entering these debates as public figures at a considerable cost and without a real benefit - other than to bolster their own national credentials as defenders of the nation and of the national interest.

In the post-1989 period, these issues have been extensively impacted by the broad geopolitical shifts in post-communist Balkans as well as by the effects of the post-1989 European unification. The 1990's agenda of turning the EU into the United States of Europe has caused various and contradictory responses from the European public. For example, the Habermas-Derrida "Core Europe" proposal [54] called for delaying or postponing the expansion of full membership benefits to the new post-2004 East European EU member states. This proposal was greeted with hostile remarks that such strategies of exclusion are to a degree anti-European or that they pave the way towards a segmentation of European unity. It is not accidental that Eastern European reaction centered precisely on this issue of Eastern Europeans being made to feel like second-class citizens.

Geopolitical, cultural and religious considerations have played and continue to play a major role in determining each country's response and understanding of the European project. Csergo and Goldgeier [55] point out that the European states' strategies vis-à-vis the EU are shaped to a considerable degree by whether the EU is viewed as an alliance of states or as a union of nations. Even more so, the public of states like Greece often expresses a positive evaluation of Europe or the EU, not as an expression of supranational sentiment but, rather, because it views Europe and the EU as shields against geopolitical instability or real and perceived threats emanating from Turkey or other states. Issues of "national interest" and of national identity provide important arenas to register discontent with the accelerated pace of Europeanization and also to assert the necessity for protection of national difference.

It is not accidental that since the early 1990s the Orthodox Church of Greece has publicly sided with the Serb side in the wars of the Yugoslav succession [56]. Public support for the Serb Orthodox 
brethren has been consistent with popular post-Cold War geopolitical thinking in Greece whereby the goal of forming a Balkan-wide Orthodox alliance against Muslim or more accurately Turkish "threats" was widely circulated and discussed. The late Archbishop Christodoulos also favored this line of thinking ([28], p. 202). His writings over time reveal a consistent image of Turkey as the "organic successor" to a barbarian Ottoman Empire that enslaved the Greek nation for nearly 400 years. Predictably, in his view, EU membership is not a realistic option for Turkey.

These geopolitical issues connected geopolitical matters directly with religious rhetoric and were extremely influential during the 1990s - especially in light of the wars of the Yugoslav succession. Of greater importance for Greece itself, however, was the 1991 declaration of independence of the former Yugoslav Republic of Macedonia. The claim to use the term "Macedonia" (which is also the name of the adjacent Greek province) and the historical national mythology of the new nation clashed directly with Greek national narrative [57]. Greece objected to the recognition of the new state on the grounds that the use of the name Macedonia is an infringement upon Greece's cultural heritage. This set off a diplomatic and geopolitical confrontation that remains unresolved to this day.

Within Greece, ecclesiastic leaders lent their support to the Greek cultural warriors who set out to defend the nation's honor against those with softer viewpoints (who were accused of being less patriotic). Among them one can find several ecclesiastical leaders who have lent their support to the cultural battles in defense of the nation's honor. Metropoliran Serafim of Piraeus, known for more hard-core or extreme views as well as Metropolitan of Mesogea Nikolaos, known for softer views, are two of them. However, the Greek public is arguably far more familiar with the views voiced by Metropolitan Anthimos of Thessaloniki (the second largest city in Greece and located in the Greek part of geographical Macedonia). In large part, this is because his Sunday oratory is regularly broadcasted by Greece's state TV channel ERT-3. Anthimos is a well-known outspoken opinion maker who routinely rallies nationalist sentiment in favor of hard-core views on the Macedonian issue.

Moreover, since 2000 a new ultra-right wing political party entered Greek politics: Popular Orthodox Rally (Laikos Orthodoxos Synagermos or LAOS) was created by former conservative MP G. Karatzaferis. The party succeeded in capturing sufficient votes to establish itself in Greece's political landscape. Unlike its predecessors, the party has a clear-cut agenda that is similar to other European right-wing parties - including featuring nationalism and anti-immigrant sentiments as key elements in its political agenda. The political use of Orthodoxy is quite explicit in the party's official title, and Karatzaferis himself has repeatedly highlighted his amicable relationship with late Archbishop Christodoulos. The party naturally adopted hard-core positions on the Macedonian issue as well.

It seems reasonable to suggest the existence of a certain ideological alliance between Orthodox Christianity and political conservatives. Such an overlap is also displayed in the public opinion data [20], but of course this is a global phenomenon. Religious adherents tend to be conservative and, therefore, they are far more likely to support politically conservative parties. It is however quite mistaken to consider that the viewpoints on the Macedonian Question or similar geopolitical issues (such as the Athens-Ankara disagreements over the Aegean) can be reduced to the conventional political division between the Left and the Right.

More specifically, with regard to the post-1991 Macedonian controversy, it might be quite convenient to use Metropolitan Anthimos' numerous and colorful statements as indicators of the nationalist posture of the Church of Greece. What such an exercise leaves out however, is the 
inconvenient truth that policy positions with regard to issues of national interest are not easily reducible to Left versus Right juxtapositions. In fact, as far as public debate on these issues is concerned, one has to concede that the existence of pluralistic perspectives that vary across party lines offers evidence of a vibrant public sphere where discourse and debate do not degenerate into predictable partisanship.

Consider the following comments made in an interview offered by Mikes Theodorakis, the world renowned Greek composer and an icon of the Greek Left [58]:

$Q$ : Many view the word patriotism as an insult today. How do you define it and how does it differ from nationalism?

A: An insult from whom, and for whom? I declare myself a patriot and I adore the Greek nation. Simultaneously, I am an internationalist and a utopian communist. Let anyone come and challenge me. I remind you that all these concepts-homeland, nation, internationalism and communism - were my guides in my every step, work, decision and act from the very beginning, in 1940, when we entered the war, until today. That gives me the right, for my part, to consider whoever battles these concepts as mudslingers.

The above is not an isolated comment. Theodorakis has consistently adopted what is often considered a "hard-core" Greek nationalist attitude with regard to the Macedonian Question. As far back as 2004, Theodorakis had stunned many among Greece's more progressive intelligentsia by issuing a public statement in which he clearly and openly took the so-called "nationalist" position with regard to the infamous Athens-Skopje "name dispute" (i.e., the dispute about whether the former Yugoslav Republic of Macedonia should be recognized as the "Republic of Macedonia" by Greece and the international community). In that statement, Theodorakis [59] declared that:

With regard to Skopje, it will be necessary to underline, I think, that the element which makes us rise and be like one man against the name "Republic of Macedonia", is naturally not with the words but with what some factions visibly signal behind these words, namely the irredentist claims against our country's territorial integrity [emphasis in the original]. This is something that unfortunately was not made sufficiently known, with the well-known results. Today, it is therefore time to resoundingly shout in every direction, and chiefly to Skopje itself, so that there will be no delusion regarding our future stance-which in every instance will be what it always has been whenever our national integrity has faced dangers.

In accordance to these views, the Greek composer has created and leads a movement of concerned citizens by the name "Spitha" (Spark) [60]. This movement gained prominence in Greece in the aftermath of the 2008 global financial crisis and the country's fiscal problems. The movement combines a nationalistic orientation with a Leftist agenda. Among the public intellectuals associated with this group, is well-known public intellectual and editor George Karabelias, who is also known for his semi-academic, semi-journalistic writings [61]. The Theodorakis' case is not an isolated incident, and it is used in this discussion for illustrative purposes because of the composer's high profile. It clearly demolishes the simplistic equation between a progressive left and a reactionary right. It illustrates the complexity of issues of "national interest" and the variety of positions adopted in public discourse. The Church hierarchy's participation in these debates should be subsequently placed in this 
broad and complex cultural context. The high clergy's own participation in these debates over "national interest" offer a means of showcasing the hierarchy's national credentials and to bolster in the public's mind its self-image as guardians of the nation. That is, the church hierarchy's vocal role in these debates does not intend on shaping Greece's foreign policy on specific issues - it is in fact quite doubtful that the hierarchs have the influence to do so. The real benefit is that, thanks to their participation in such debates, the hierarchs bolster their self-image which is subsequently capitalized on domestic issues in which the public's support is needed to persuade the government to adopt policies in accordance to the church's interests.

\section{Conclusions}

In this article, I have offered an overview of Greece's engagement with the politics of heritage and memory and concentrated in particular on the role of Orthodox Christianity in these debates. Greece's engagement with these issues is part of a broader European engagement with this problem. The collapse of communism in Eastern Europe, which had a dramatic impact on European social, economic and political affairs, provided the general context for the reassertion of religion into Greece's cultural politics. This should not be viewed in isolation from broader trends. During the post-1989 period, the most popular response among Orthodox national churches throughout Eastern Europe has been to cling to their version of the modern synthesis of church and nation in the face of contemporary globalization (for discussions of individual cases, see Roudometof et al. [62]). Orthodox intellectuals and religious leadership within Greece were not an exception from this broader tendency.

Obviously, this article could not possibly exhaust this rich and complex topic but offers only a sketchy account of specific "hot issues" of ecclesiastical involvement in public culture and several issues of national heritage. These various topics provide arenas where two competing groups of intellectuals offer radically opposite interpretations of these issues. The article offers a brief overview of the interpretations of these two opposing groups, arguing that, in order to gain perspective, one needs to view their cultural battles as a form of ongoing public negotiation of the relationship between Greece and the broader European project. In this respect, Greece's debates on these hot topics echo similar disputes that take place throughout Europe. Just as in other European states, political partisanship colors these debates. The proponents of the Church tend to be mostly on the right, whereas progressive intellectuals tend to be mostly on the left. However, this is an imperfect generalization with many exceptions. Certainly, political parties take advantage of this right for political purposes - as is the case with the Greek ultra right-wing party LAOS.

In Greece's case, there are three different levels of generality with respect to the range of issues where the Church and Eastern Orthodox Christianity in general is implicated. First, there are the most specific ecclesiastical issues, such as the cremation of the dead or the issue of burial rites and baptism for those who had a civil wedding. These are topics about which the Church enjoys an authoritative position. Some of these issues have more to do with the interpretation of Canon Law and less with national history or heritage per se. Second, there is a broad range of more diffuse topics, such as the listing of religious affiliation on ID cards, the operation of mosques or the Costa Gravas video. These are topics that do not concern the Church alone. Rather, the state and various other constituencies within the public voice their own opinions and also shape the final outcome in each case. In other 
words, in these topics, the Church has to compete for the legitimacy of its viewpoints vis-à-vis other parties. This is also the category in which the "use of the past" becomes a highly contested and publicly deliberated issue. Third, there are some broad political issues, such as geopolitics or issues of national interest and foreign policy. Although the perspectives expressed on such topics-like the Macedonian Question - are certainly colored by considerations of national memory and heritage, it is far from the only consideration. Foreign policy issues often are decided with realism and geopolitics in mind and the state is a privileged player in these affairs. In this domain, the Church has only limited ability to influence outcomes, as it is only one of several agents in the public scene. Certainly, it can voice its own perspectives but with far less appeal than on ecclesiastical issues.

In the above classification it is important to note the porous boundaries separating the more clear-cut ecclesiastical issues from those who involve decision-making by the State and other constituencies. In the course of this article, I have suggested that it is precisely because of the porous nature of these boundaries that the Church hierarchy is motivated to enter into the public discourse. By doing so, the high clergy can use their influence and their public image as defenders of the nation to rally public support over an entire range of issues where the active support of the State is badly needed if legislation is going to be favored toward the Church's own position. This strategy actually accounts for the high clergy's participation into debates over issues of national interest, where the Church lacks any superior role and where it is quite doubtful that it can effectively guide foreign policy.

Needless to say, ecclesiastical leadership will undoubtedly persist to voice its opinions on this entire range of topics. In 2008, after the passing of Christodoulos, the election of Ieronimos to the Archbishopric of Athens and all of Greece signaled a new course in the Church's public involvement. Ieronimos has been soft spoken, far more liberal, less openly nationalistic than was his predecessor and unwilling to turn himself into a TV personality. His election signaled a victory for those hierarchs who considered that the Church had suffered from media "overexposure" during the late archbishop's tenure and that it was time to adopt a more subdued public persona. But still, as the Parthenon video affair illustrates, this does not mean that the Church hierarchy is willing to cease expressing its views when it feels it is necessary to protect the Church's reputation from what is perceived as unjustified criticism.

\section{References and Notes}

1. Levi, G., Revel, J., Eds. Political Uses of the Past: The Recent Mediterranean Experience; Routledge: London, UK, 2002.

2. Roudometof, V. Collective memory and cultural politics: An introduction. J. Polit. Mil. Sociol. 2007, 35, 1-16.

3. Nora, P. Realms of Memory: The Construction of the French Past; Columbia University Press: New York, NY, USA, 1996-1998.

4. Lowenthal, D. The Heritage Crusade and the Spoils of History; Cambridge University Press: Cambridge, UK, 1998.

5. Graham, B.; Ashworth, G.J.; Turnbridge, J.E. A Geography of Heritage: Power, Culture and Economy; Arnold: London, UK, 2000. 
6. Hunter, J. Culture Wars: The Struggle To Control The Family, Art, Education, Law, And Politics In America; Basic Books: New York, NY, USA, 1992.

7. Taylor, C. The politics of recognition. In Multiculturalism: Examining the Politics of Recognition; Taylor, C., Appiah, K.A., Habermas, J., Rockefeller, S.C., Walzer, M., Wolf, S., Eds.; Princeton University Press: Princeton, NJ, USA, 1994; pp. 25-74.

8. Cornwell, G.H., Stoddard, E.W. Global Multiculturalism: Comparative Perspectives on Ethnicity, Race and Nation; Rowman and Littlefield: Lanham, MD, USA, 2001.

9. Makrides, V.N. Hellenic Temples and Christian Churches: A Concise History of the Religious Cultures of Greece from Antiquity to the Present; New York University Press: New York, NY, USA, 2009.

10. Yannas, P. Non-Orthodox minorities in contemporary Greece: Legal status and concomitant debates between Church, state and international community. In Orthodox Christianity in $21^{\text {st }}$ Century Greece: The Role of Religion in Culture, Ethnicity and Politics; Roudometof, V., Makrides, V.N., Eds.; Ashgate: Aldershot, UK, 2010; pp. 111-130.

11. Roudometof, V. Nationalism, Globalization, and Orthodoxy: The Social Origins of Ethnic Conflict in the Balkans (Westport, CT: Greenwood, 2001) for a full overview of the literature concerning the situation of Orthodox Christians under Ottoman rule as well as later developments.

12. Roudometof, V. Greek-Orthodoxy, territoriality and globality: Religious responses and institutional disputes. Sociol. Relig. 2008, 68, 67-91.

13. Roudometof, V. Ethnic heterogeneity, cultural homogenization, and state policy in the inter-war Balkans. In Ethnic Cleansing in Twentieth-Century Europe; Vardy, S.B., Tooley, H., Eds; East European Monographs: Boulder, CO, USA, 2003; pp. 219-235.

14. Anderson, B. Imagined Communities, 2nd ed.; Verso: London, UK, 1991.

15. Barth, F., Ed. Ethnic Groups and Boundaries: Social Organization of Culture Differences Little, Brown, and Co.: Boston, MA, USA, 1969.

16. Margaritis, Y. Undesired Compatriots (in Greek); Vivliorama: Athens, Greece, 2005.

17. McNeill, W. The Metamorphosis of Greece Since World War II; University of Chicago Press: Chicago, IL, USA, 1978.

18. Georgiadou, V.; Nikolakopoulos, I. The people of the church. In Public Opinion in Greece (in Greek); Vervardakis, C., Ed.; VPRC-Livanis: Athens, Greece, 2001; pp. 141-185.

19. Makrides, V.N. The Orthodox Church and the post-war religious situation in Greece. In The PostWar Generation and Establishment Religion: Cross-Cultural Perspectives; Roof, W.C., Carroll, J.W., Roozen, D.A., Eds.; Westview: Boulder, CO, USA, 1995; pp. 225-242.

20. Gazi, E. The Second Life of the Three Hierarchs: A Genealogy of the "Graeco-Christian Civilization (in Greek); Nefeli: Athens, Greece, 2004.

21. Alivizatos, N.C. A new role for the Greek Church? J. Mod. Greek Stud. 1999, 17, 23-39.

22. Roudometof, V. Orthodoxy as public religion in post-1989 Greece. In Eastern Orthodoxy in a Global Age: Tradition Meets the 21st Century; Roudometof, V., Agadjanian, A., Pankhurst, J., Eds.; Alta Mira Press: Walnut Creek, CA, USA, 2005; pp. 84-108.

23. Stavrakakis, Y. Politics and religion: On the "politicization" of Greek Church discourse. J. Mod. Greek Stud. 2003, 21, 153-182. 
24. Roudometof, V., Makrides, V.N. Orthodox Christianity in $21^{\text {st }}$ Century Greece: The Role of Religion in Culture, Ethnicity and Politics; Ashgate: Aldershot, UK, 2010.

25. Makrides, V.N.; Roudometof, V. Tradition, transition and change in Greek Orthodoxy at the dawn of the twenty-first century: Introductory considerations. In Orthodox Christianity in 21 st Century Greece: The Role of Religion in Culture, Ethnicity and Politics; Roudometof, V., Makrides, V.N., Eds.; Ashgate: Aldershot, UK, 2010; pp. 1-18.

26. Oulis, D.; Makris, G.; Roussos, S. The Orthodox Church of Greece: Policies and challenges under Archbishop Christodoulos of Athens (1998-2008). Int. J. Stud. Christ. Church 2010, 10, 192-210.

27. Christodoulos (Paraskeuaidis), Archbishop of Athens and All Greece. Of Soil and Heaven (in Greek); Kastaniotis: Athens, Greece, 1999.

28. Hervieu-Léger, D. Religion as a Chain of Memory; Rutgers University Press: New Brunswick, NJ, USA, 2000.

29. Andrianopoulos, A. Hellenism and Orthodoxy (in Greek); Kaktos: Athens, Greece, 2001.

30. Papageorgiou, N. The Church in Modern Greek Society (in Greek); Pournaras: Thessaloniki, Greece, 2000.

31. Danopoulos, C.P. Religion, civil society and democracy in Orthodox Greece. J. Southern Eur. Balkans 2004, 6, 41-56.

32. Prodromou, E.H. Negotiating pluralism and specifying modernity in Greece: Reading churchstate relations in the Christodoulos period. Soc. Compass 2004, 51, 471-485.

33. Makrides, V.N. L' Autre' Orthodoxie: Courants du rigorisme Orthodox Grec. Soc. Compass 2004, 51, 511-521.

34. Molokotos-Liederman, L. Identity crisis: Greece, Orthodoxy, and the European Union. $J$. Contemp. Relig. 2003, 18, 291-315.

35. Molokotos-Liederman, L. Looking at religion and Greek identity from the outside: The identity cards conflict through the eyes of Greek minorities. Relig. State Soc. 2007, 35 139-161.

36. Molokotos-Liederman, L. The Greek ID card controversy: A case study of religion and national identity in a changing European Union. J. Contemp. Relig. 2007, 22, 187-203.

37. Dimitropoulos, P. State and Church: A Difficult Relationship (in Greek); Kritiki: Athens, Greece, 2001.

38. Mavrocordatos, G.T. Orthodoxy and nationalism in the Greek case. In Church and State in Contemporary Europe: The Chimera of Neutrality; Madeley, J.T.S., Enyedi, Z., Eds.; Frank Cass: London, UK, 2003; pp. 117-136.

39. Antoniou, D. The mosque that wasn't there: Ethnographic elaborations on Orthodox conceptions of sacrifice. In Orthodox Christianity in $21^{\text {st }}$ Century Greece: The Role of Religion in Culture, Ethnicity and Politics; Roudometof, V., Makrides, V.N., Eds.; Ashgate: Aldershot, UK, 2010; pp. 155-174.

40. Ng, D. Acropolis Museum Backs Down in Costa-Gavras Film Row. http://uk.reuters.com/article/idUKTRE5733W020090804 (accessed on 4 August 2010).

41. Antivaro. Special on the New School Textbook for the 6th Grade of Elementary Schools; http://palio.antibaro.gr/istoria.php\#biblio (accessed on 27 August 2010).

42. Angelou, A. The Underground School: Chronicle of a Myth (in Greek); Hestia: Athens, Greece, 1999. 
43. Giannakou, M. Interview, Marietta Giannakou, 2 August 2007; http://www.giannakou.gr/index.php?page=view_article\&news_id=4 (accessed on 27 August 2010). The role of right-wing deputies (belonging to the ultra right-wing party LAOS, to be discussed later on in the article) should be also be noted. Their actions and criticisms contributed to the media frenzy.

44. See the February 282011 discussion titled "Can we put up with the idea of discussing our history?" available on line at http://folders.skai.gr. Panelists included historians Thanos Veremis and Nikos Panayiotopoulos, philosopher ChristosYannaras and Metropolitan of Thessaoniki Anthimos.

45. Having been asked to name specific individuals who belong to these two camps, the following tentative list is offered. This list also echoes the reviewers' remarks and suggestions. Those belonging to the first camp include philosophers Christos Yannaras, Law professor I. Konidaris and former University professor Costas Zouraris as well as clergyman Ft. Georgios Metallinos. Stelios Ramfos is an idiosyncratic thinker whose views are often cited as belonging to the "NeoOrthodox" camp, yet his ideas are quite different from the other people cited above. Those belonging to the second "modernizing" camp are themselves split between liberals and Leftists. Liberals include historians Thanos Veremis and Ioannis Koliopoulos and Prof. of Education Maria Repousi. Leftists include historians Th. Liakos and Effie Gazi, sociologist Constantine Tsoucalas, Education professor Thalia Dragona and political philosopher Giannis Stavrakakis. This list of names is only a partial account, offered here simply for illustrative purposes.

46. Ramfos, S. The Inconceivable Nothing (in Greek); Armos: Athens, Greece, 2010.

47. Yannaras, Chr. Orthodoxy and the West in Modern Greece (in Greek); Domos: Athens, Greece, 1992.

48. Lipowatz, T. Orthodox Christianity and nationalism: Two aspects of the modern Greek political culture (in Greek). Greek Polit. Sci. Rev. 1993, 2, 31-47.

49. Mappa, S. Orthodoxy and Authority in Greek Society (in Greek); Exantas: Athens, Greece, 1997.

50. Pollis, A. Greek National Identity: Religious Minorities, Rights, and European Norms. J. Mod. Greek Stud. 1992, 10, 171-195.

51. Fokas, E. Greek Orthodoxy and European identity. In Contemporary Greece and Europe; Achilleas, M., Mossialos, E., Eds.; Ashgate: Aldershot, UK, 2000; pp. 175-192.

52. Karagiannis, E. Secularism in context: The relations between the Greek state and the Church of Greece in crisis. Eur. J. Sociol. 2009, 50, 133-167.

53. Nikolopoulos, P.D. Privatization of Religion and Secularization of the Church (in Greek); Kastaniotis: Athens, Greece, 2005.

54. Levy, D., Pensky, M., Torpey, J., Eds. Old Europe, New Europe, Core Europe: Transatlantic Relations after the Iraqi War; Verso: London, UK, 2005.

55. Csergo, Z.; Goldgeier, J.M. Nationalist strategies and European integration. Perspecti. Polit. 2004, 2, 21-37.

56. Michas, T. Unholy Alliance: Greece and Milosevic's Serbia; Texas A \& M University Press: College Station, TX, USA, 2002.

57. Roudometof, V. Collective Memory, National Identity and Ethnic Conflict: Greece, Bulgaria and the Macedonian Question; Praeger: Westport, CT, USA, 2002. 
58. Gilson, G. Interview with Mikis Theodorakis, Athens News, 21 June 2010; pp. 10-11, http://www.athensnews.gr/articles/13367/07/12/2009/24111 (accessed on 28 August 2010).

59. Theodorakis, M. Public Statement, 10 November 2004; http://en.mikistheodorakis.net/index.php/article/articleview/398/1/10/ (accessed on 28 August 2010).

60. Spithabook; http://www.spitha-kinima.org/ (accessed on 4 May 2011).

61. See the Ardin/Rixi website at www.ardin.gr (accessed on 4 May 2011).

62. Roudometof, V., Agadjanian, A., Pankhurst, J., Eds. Eastern Orthodoxy in a Global Age: Tradition Meets the $21^{\text {st }}$ Century; Alta Mira Press: Walnut Creek, CA, USA, 2005.

(C) 2011 by the authors; licensee MDPI, Basel, Switzerland. This article is an open access article distributed under the terms and conditions of the Creative Commons Attribution license (http://creativecommons.org/licenses/by/3.0/). 